\title{
SISTEM PEMANTAUAN DAN PENGENDALIAN RUMAH JAMUR DENGAN METODE FUZZY SECARA WIRELESS
}

\author{
Firdaus Iman Ubaidillah \\ Fakultas Teknik, Jurusan Teknik Elektro \\ Universitas Widyagama Malang \\ Email: firdausiman.ubaidillah@gmail.com \\ Istiadi \\ Fakultas Teknik, Jurusan Teknik Informatika \\ Universitas Widyagama Malang \\ Email: istiadi@widyagama.ac.id \\ Muhamad Mukhsim \\ Fakultas Teknik, Jurusan Teknik Elektro \\ Universitas Widyagama Malang \\ Email: 07.muhsin@gmail.com
}

\begin{abstract}
ABSTRAK
Pembudidayaan jamur tiram perlu dibuat rumah atau kumbung jamur dengan kondisi yang harus selalu di pantau agar jamur dapat tumbuh dengan baik. Dalam penelitian ini dikembangkan sistem pemantauan dan pengendalian rumah jamur dengan metode fuzzy logic control yang dilakukan wireless. Sistem pengendali menggunakan sensor AM2301 untuk pembacaan nilai kelembaban udara dan suhu yang terhubung dengan Arduino UNO yang terintegrasi dengan ESP8266. Pembacaan data sensor secara periodik dan secara otomatis mengontrol kipas, lampu dan pompa serta mengirimkannya untuk dilakukan pemantauan. Metode pengendalian yang digunakan adalah fuzzy logic control tipe Mamdani. Dari penelitian ini dihasilkan sistem yang dapat mengendalikan suhu melalui kecepatan kipas dan lama waktu lampu menyala, sedangakan untuk kelembaban udara melalui lama waktu pompa menyala. Hasil perancangan dapat dikatakan sesuai dengan plant, karena output dapat bekerja sesuai dengan aturan fuzzy logic control yang diinginkan dan data dapat terkirim serta di terima untuk pemantauan.
\end{abstract}

Kata kunci: jamur tiram; rumah jamur; fuzzy logic control; wireless.

\section{ABSTRACT}

Oyster mushroom cultivation requires a culture house, with conditions that must always be monitored so that the fungus can grow well. In this research, a monitoring and control system of mushroom houses was developed using a wireless fuzzy logic control method. The control system uses the AM2301 sensor for reading the humidity and temperature values connected to the Arduino UNO integrated with ESP8266. Data from the sensor is periodically read and automatically used as a consideration for controlling fans, lights and pumps and sending them for monitoring. The control method used is the Mamdani type fuzzy logic control. From this study produced a system that can control temperature through fan speed and length of time the lamp is on, while for air humidity through the length of time the pump is running. The design results are in accordance with the requirements, because the output can work in accordance with the desired fuzzy logic control rules and data can be sent and received for monitoring.

Keywords: oyster mushroom; mushroom house; fuzzy logic control; wireless.

\section{PENDAHULUAN}

Jamur tiram (Volvariella volvacea) termasuk tumbuhan yang banyak tumbuh pada sisa tanaman yang telah mati dan area yang lembab. Jamur tiram termasuk jamur yang dapat dikonsumsi. Jamur tiram banyak mengandung protein serta vitamin cukup tinggi, dan merupakan jamur yang sering di konsumsi masyarakat $[1]$.

Jamur tiram membutuhkan lignin, yang digunakan sebagai sumber nutrisinya. Kemudian lignin diubah menjadi molekul gula, molekul yang lebih sederhana dengan menggunakan enzim ligninase yang dihasilkan oleh jamur. Lignin dapat ditemukan pada limbah pertanian yang banyak dijumpai. Limbah tersebut juga mengandung selulosa, protein, dan vitamin yang dibutuhkan untuk mendukung pertumbuhan jamur. Selain itu jamur tiram juga membutuhkan suhu antara 25-28 C dan kelembaban 70-80\% untuk tumbuh [2], [3]. 
Meskipun jamur tiram lebih optimal tumbuh dengan baik pada daratan tinggi, namun seiring dengan perkembangan teknologi budidaya jamur juga dapat dilakukan di dataran rendah dengan rumah jamur yang dilengkapi dengan pengatur kelembaban sehingga pertumbuhan jamur dapat tumbuh optimal [2].

Pertumbuhan jamur tiram mulai dari tahap tumbuh sampai siap panen dipengaruhi dengan suhu dan kelembaban yang terkendali dalam rumah jamur. Namun para pembudidaya jamur tiram saat ini masih menggunakan cara konvensional dalam proses pengendaliannya, sehingga mengharuskan pembudidaya melakukan penyiraman atau pembasahan lahan secara manual dengan tenaga manusia dan penurunan suhu ruang dengan menyalakan kipas pendingin atau membuka ventilasi udara. Hal ini dikarenakan pada waktu penyiraman dan pendinginan sangat bergantung pada kondisi cuaca. Maka para pembudidaya perlu melakukan pemantauan secara periodik terhadap keadaan rumah jamur pada selang waktu tertentu [2]. Hal tersebut membuat budidaya jamur tiram dinilai kurang efisian, karena banyak menguras tenaga dan sangat bergantung pada para pembudidaya dalam pengendalian keadaan pada rumah jamur [1]. Maka dari itu diperlukan sebuah alat untuk memudahkan budidaya jamur, yaitu pada saat pemantauan dan pengendalian keadaan rumah jamur secara wireless. Jadi meskipun tanpa harus ke rumah jamur tersebut pengendalian serta pemantauan masih dapat dilakukan.

Upaya pemantauan dan pengendalian rumah jamur secara elektronik telah dilakukan sebelumnya. Pada [4], telah dikembangkan sistem pengendali rumah jamur menggunakan PLC, sehingga membutuhkan biaya yang cukup besar untuk pengadaan perangkatnya. Pada [5], telah dikembangkan pengendali rumah jamur yang hanya memperhatikan faktor suhu . Pada [2] dan [6] sudah mengembangkan suhu dan kelembaban mikrokontroler, sehingga lebih murah tetapi dalam perancangannya belum dapat dimonitor secara wireless. Pada [1] lebih ditekankan pada mengembangkan pengukuran dan pemantaun rumah jamur berbasis IoT tetapi tidak menekankan pada aspek pengendalian yang otomatis. Suatu system pengendali elektronik memerlukan suatu pendekatan atau metode agar dapat bekerja secara efektif. Salah satu pendekatan tersebut dengan menggunakan metode Logika fuzzy [2].

Logika fuzzy sudah sering digunakan pada banyak pengendalian otomatis di industri dan mesin. Salah satu fungsinya adalah sebagai pengendali motor, robot, dan sensor [7]. Banyak aplikasi dari suatu sistem pengendali atau kontrol dengan menggunakan sistem fuzzy, karena relitif lebih mudah pembuatannya tanpa melibatkan model matematis yang rumit dari suatu sistem pengendalian yang akan dibuat [8].

Pada pembuatan sebuah sistem pengendali dengan metode logika fuzzy terdapat tiga proses, pertama fuzzifikasi (fuzzification) kemudian dilanjutkan proses evaluasi rule (rule evaluation), dan proses yangterakhir adalah proses defuzzifikasi (defuzzification). Dari setiap dari ketiga proses tersebut akan mempengaruhi suatu respon dari sistem yang akan dikendalikan [8], [9].

Berdasarkan masalah tersebut, penelitian ini melakukan suatu pengembangan sistem yang dapat memantau keadaan suhu dan kelembaban udara pada rumah budidaya jamur tiram dengan metode fuzzy agar parameter yang ditetapkan dapat dikendalikan, serta menggunakan perangkat wireless, untuk mempermudah pemantauannya meskipun tidak langsung ke tempat pembudidayaannya [10].

Dalam penelitian ini suhu dan kelembaban sudah ditentukan dari data yang ada. Mikrokontroler yang digunakan adalah Arduino Uno tipe R3 dangan perangkat wireless ESP8266. Untuk sensor yang digunkan adalah sensor DHT21 atau AM2301. Penelitian ini menggunakan prototype sebagai bahan penelitian.

\section{METODOLOGI PENELITIAN}

Perancangan sistem ini dibagi menjadi beberapa bagian, pertama adalah perangkat keras dan kedua adalah perangkat lunak. Seluruh perancangan perangkat keras dijelaskan pada Gambar 1.

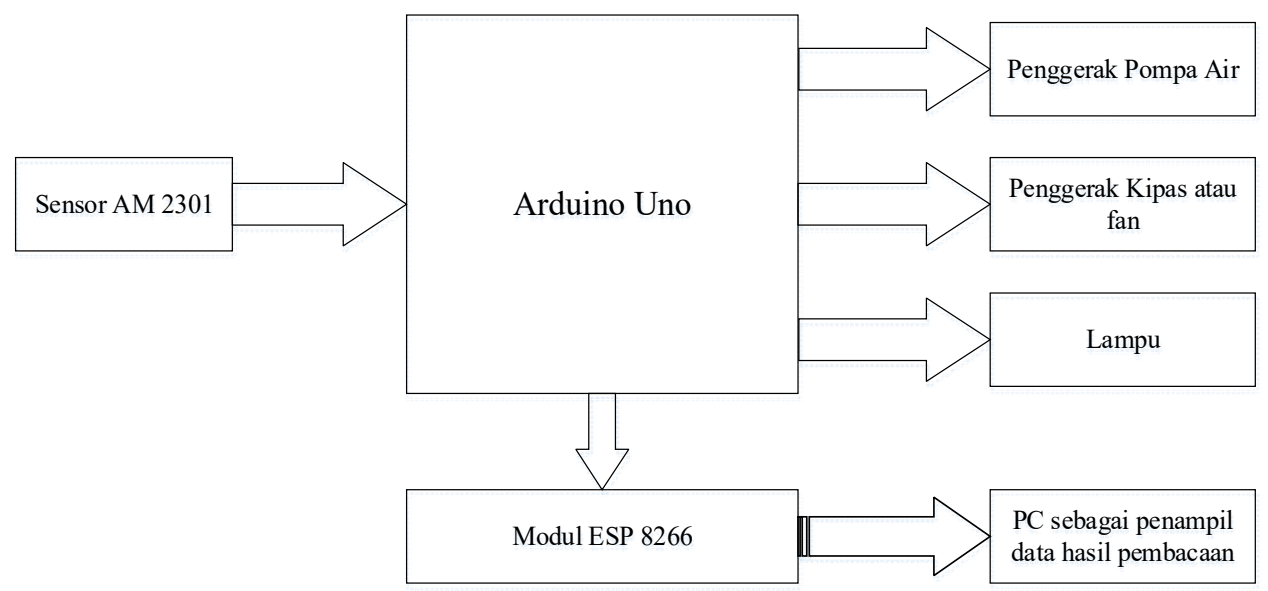

Gambar 1. Rangkaian Perangkat Keras 
Pada gambar 1 dapat diketahui Sensor AM2301 digunakan sebagai alat untuk membaca suhu dan kelembaban pada rumah jamur. Arduino Uno digunakan sebagai penerima hasil pembacaan sensor yang selanjutnya akan diolah menjadi luaran untuke mengendalikan actuator antara lain lampu, pompa dan kipas. Modul WiFi ESP8266 digunakan untuk komunikasi atau mengirim data dari arduino menuju PC. Driver Motor digunakan untuk menjembatani antara arduino dengan kipas. Pompa motor DC berfungsi mengalirkan air untuk menambahkan kelembaban pada rumah jamur. Kipas atau fan berfungsi untuk mengendalikan suhu dalam rumah jamur. Laptop atau PC (personal computer) akan menampilkan data hasil pembacaan keadaan suhu dan kelembaban di rumah jamur [11].

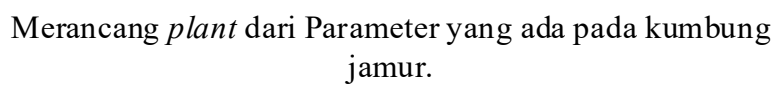

Merancang Input FLC dengan parameter :

Suhu dan kelembaban

\author{
Merancang Output FLC dengan parameter yang ada \\ untuk: \\ Kipas, lampu dan pompa
}

\title{
Gambar 2. Perencanaan Perangkat Lunak
}

Pada gambar 2 dapat dilihat alur proses yang dimulai dari parameter input dan output pada rumah jamur yang akan dibaca ke dalam fungsi keanggotaan dari metode fuzzy. Implementasi metode logika fuzzy merupakan penuangan bahasa pemrograman di dalam mikrokontroler [12]. Hasil dari pengolahan metode fuzzy akan diteruskan ke kipas, lampu dan pompa. Parameter yang digunakan adalah suhu dan kelembaban yang didapatkan dari pembacaan sensor.

\subsection{Perancangan Fuzzy Logic untuk Sistem Kontrol}

Fuzzifikasi adalah proses pengubahan nilai data dari sensor (nilai tegas) ke dalam bentuk himpunan fuzzy yang digolongkan pada fungsi keanggotaan yang ada. Proses awal fuzzifikasi adalah membuat fungsi keanggotaan dari setiap input, kemudian menentukan banyaknya nilai linguistik dalam fungsi keanggotaan. Digunakan tiga buah nilai linguistic untuk sensor suhu, yang terdiri dari dingin, tepat dan panas. Input sensor suhu memiliki rentang nilai dari $0^{\circ} \mathrm{C}$ sampai $40^{\circ} \mathrm{C}$.

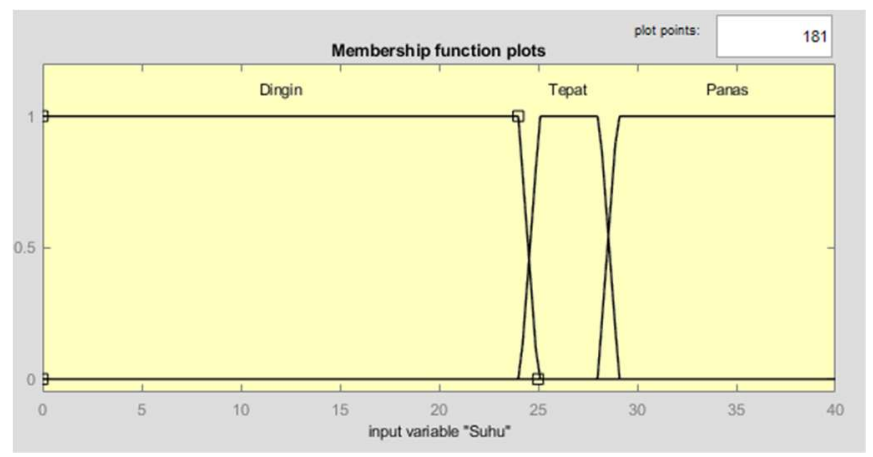

Gambar 3. Fungsi Keanggotaan Suhu

Gambar 3 menyajikan dari fungsi keanggotaan keadaan suhu pada rumah jamur yang dikategorikan menjadi dingin, tepat, dan panas. Nilai dari setiap fungsi keanggotaan suhu dapat dituliskan sebagai berikut :

a. Dingin : $(0,0,24,25)$

b. Tepat : $(24,25,28,29)$

c. Panas : $(28,29,40,40)$

Sedangkan sensor kelembaban udara juga digunakan tiga buah nilai linguistik, yang terdiri dari kering, tepat dan basah. Sensor akan mendeteksi uap air yang ada pada area sekitar sensor, dengan mengukur hambatan listrik yang terdapat diantara kedua elektroda di dalam sensor. Perubahan nilai resistansi tersebut hampir sebanding dengan nilai kelembaban relatif. Nilai kelembaban relatif yang tinggi, akan menurunkan nilai dari resistensi dari kedua elektroda didalam sensor. Jika nilai kelembaban relatif rendah, maka akan menaikkan nilai resistensi dari kedua elektrodadi dalam sensor [9]. Input sensor kelembaban udara memiliki rentang nilai dari nilai 20\% RH sampai nilai $100 \% \mathrm{RH}$. 


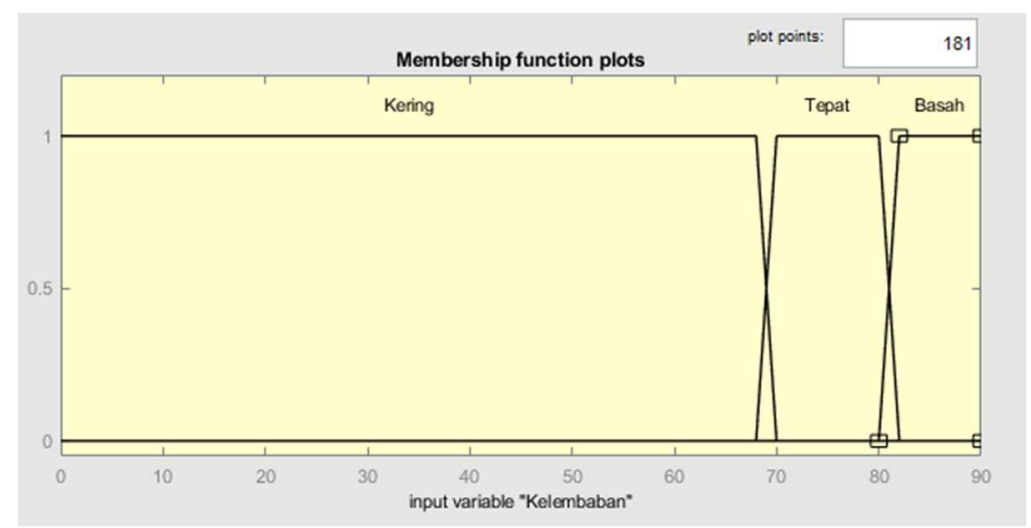

Gambar 4. Fungsi Keanggotaan Kelembaban

Gambar 4 menampilkan fungsi keanggotaan keadaan kelembaban udara pada rumah jamur yang dikategorikan menjadi kering, tepat, dan basah. Nilai dari setiap fungsi keanggotaan kelembaban udara dapat dituliskan sebagai berikut :

a. Kering : $(0,0,68,70)$

b. Tepat : $(68,70,80,82)$

c. Basah : $(80,82,90,90)$

Luaran sistem yang dikendalikan berupa kipas, lampu, dan pompa air. Kipas digunakan untuk menurunkan suhu pada area kumbung jamur. Lampu digunakan sebagai pemanas untuk menaikkan suhu pada area kumbung jamur, dan pompa digunakan untuk menambah kelembaban udara dengan cara menyiramkan air pada area kumbung jamur [11]. Metode PWM (Pulse Width Modulation) digunakan untuk mengatur pengemudian kipas hasil luaran fuzzy, sedangkan untuk pengemudian lampu dan pompa digunakan nilai waktu untuk on pada durasi waktu tertentu. Funsi keanggotaan fuzzy digunakan tiga nilai linguistik untuk kipas yaitu lambat, normal, dan cepat.

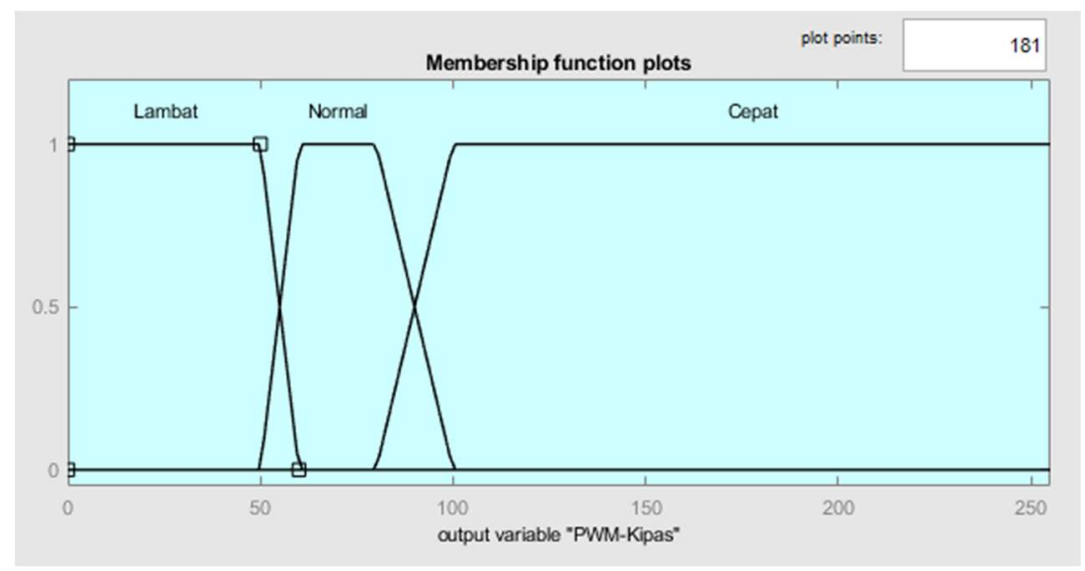

Gambar 5. Fungsi Keanggotaan Kipas

Gambar 5 menyajikan fungsi keanggotaan keadaan dari nilai PWM pada kipas yang dikategorikan menjadi lambat, normal, dan cepat. Nilai dari setiap fungsi keanggotaan dapat dituliskan sebagai berikut :

a. Lambat: $(0,0,50,60)$

b. Normal : $(50,60,80,100)$

c. Cepat : $(80,100,255,255)$ 


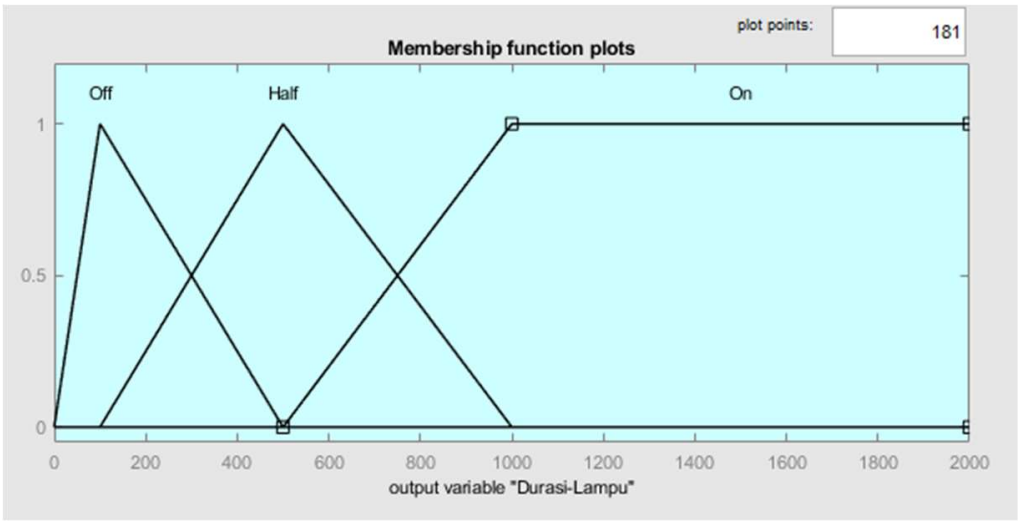

Gambar 6. Fungsi Keanggotaan Durasi Lampu

Fungsi pengendalian lampu digunakan tiga nilai linguistik yaitu Off, half, dan On yang ditunjukkan pada Gambar 6 di atas. Berikut keterangan dari fungsi keanggotaan nilai durasi lampu dalam satuan mili detik :
a. Off : $(0,100,100,500)$
b. Half: $(100,500,500,1000)$
c. On : $(500,1000,2000,2000)$

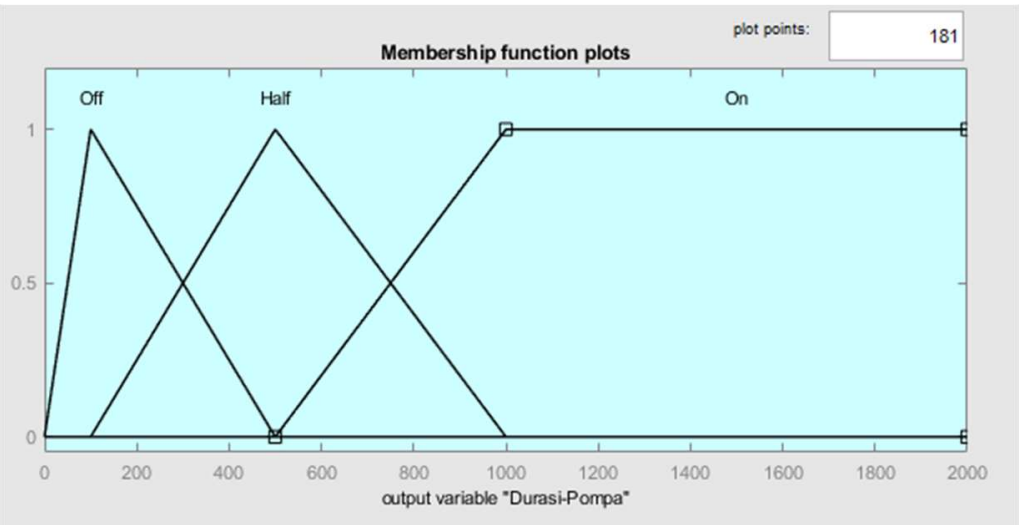

Gambar 7. Fungsi Keanggotaan Durasi Pompa

Fungsi pengendalian pompa digunakan tiga nilai linguistik yaitu singkat, sedang, dan lama yang ditunjukkan pada Gambar 7 di atas. Berikut keterangan dari fungsi keanggotaan nilai durasi pompa dalam satuan mili detik :

a. Off : $(0,100,100,500)$

b. Half: $(100,500,500,1000)$

c. On $:(500,1000,2000,2000)$

\subsection{Basis Aturan}

Basis aturan atau rule base merupakan proses untuk mengevaluasi derajat keanggotaan di setiap fungsi keanggotaan input ke dalam basis aturan yang telah ditetapkan. Pada bagian ini akan dibuat aturan-aturan dari input fuzzy dalam menentukan nilai output yang akan dikeluarkan oleh sistem pengendali. Basis aturan yang digunakan untuk pengendalian kipas ditunjukan pada Tabel 1.

Tabel 1. Basis aturan untuk kipas

\begin{tabular}{cll}
\hline No. & Suhu & PWM Kipas \\
\hline 1. & Dingin & Lambat \\
2. & Tepat & Normal \\
3. & Panas & Cepat \\
\hline
\end{tabular}


Tabel 1 menunjukkan basis aturan untuk kipas. Pada tabel itu, data suhu yang terbaca oleh sensor akan masuk pada kategori suhu yang sudah ditentukan untuk menghasilkan pengaturan kategori kecepatan kipas agar sesuai dengan kebutuhan.

Tabel 2. Basis Atutan Untuk Lampu

\begin{tabular}{clc}
\hline No. & Suhu & Durasi Waktu Lampu \\
\hline 1. & Dingin & On \\
2. & Tepat & Half \\
3. & Panas & Off \\
\hline
\end{tabular}

Tabel 2 menunjukkan basis aturan untuk lampu. Pada basis aturan itu, data suhu yang terbaca oleh sensor akan masuk pada kategori suhu yang sudah ditentukan untuk menghasilkan kategori durasi menyalaan lampu sesuai dengan kebutuhan.

Tabel 3. Basis Aturan Untuk Pompa Air

\begin{tabular}{ccc}
\hline No. & Kelembaban Udara & $\begin{array}{c}\text { Durasi Waktu } \\
\text { Pompa }\end{array}$ \\
\hline 1. & Kering & On \\
2. & Tepat & Half \\
3. & Basah & Off \\
\hline
\end{tabular}

Tabel 2 menyajikan basis aturan untuk pompa . Pada basis aturan itu, data kelembaban udara yang terbaca oleh sensor akan masuk pada kategori kelembaban udara yang sudah ditentukan untuk menghasilkan durasi menyala pompa sesuai dengan kebutuhan.

\subsection{Defuzzifikasi}

Defuzzifikasi merupakan tahap terakhir dari inferensi fuzzy, yaitu mengubah output himpunan fuzzy menjadi output nilai tegas. Defuzzifikasi (kebalikan dari proses fuzzifikasi) melakukan penggabungan dari beberapa nilai linguistik yang didapatkan. Kemudian menggunakan sebagaimana aturan mamdani yaitu dengan metode Centroid. Dengan menentukan nilai min dan max fungsi keanggotaan, menentukan batas atas dan bawah dan menghitungnya untuk mencari pusat gravitasi (Center Of Grafity) dari himpunan agregasi, seperti yang ditunjukkan dalam persamaan (1).

$$
\operatorname{CoG}=\frac{\mathrm{x} \int \mu(x) a x}{\int \mu(x) d x}
$$

\subsection{Perancangan Prototipe}

Perancangan prototipe dibagi menjadi 2 bagian yaitu bagian dari rangkaian pengendali dan rumah jamur. Berikut desain dari perancangan prototipe rumah jamur yang dibuat.
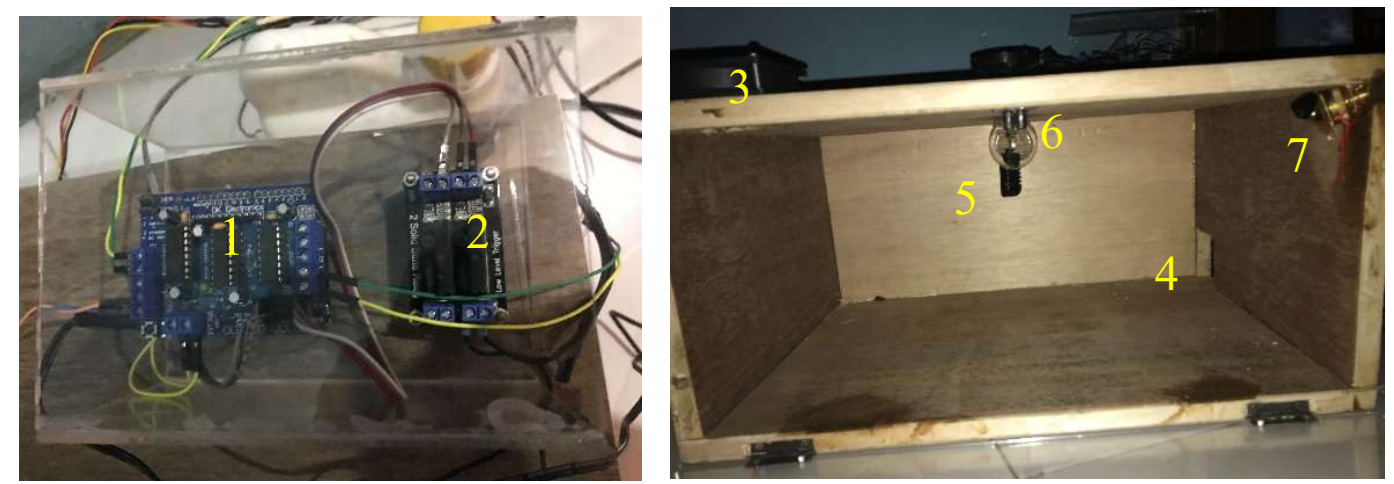

Gambar 8. Desain Rancang Bangun Rumah Jamur 
Gambar 8 menunjukkan desain dari prototype rumah jamur. Bagian-bagian sistem rumah jamur sesuai Gambar 8 adalah sebagai berikut.

a. Pada angka 1 adalah board Arduino uno dan driver motor

b. Pada angka 2 adalah board solid state relay (SSR).

c. Pada angka 3 dan 4 adalah letak dari kipas.

d. Pada angka 5 adalah letak dari sensor AM2301.

e. Pada angka 6 adalah letak dari lampu.

f. Pada angka 7 adalah letak dari saluran air dari pompa.

g. Sedangkan untuk pompa diletakkan pada belakang rumah jamur.

\section{HASIL DAN PEMBAHASAN}

Pengujian kendali suhu dan kelembaban meliputi pengujian hasil output metode logika fuzzy pada kipas, lampu dan pompa pada beberapa keadaan suhu dan kelembaban yang dibaca oleh sensor.

\subsection{Pengujian Nilai PWM Kipas}

Pengujian ini meliputi pengujian kipas dengan bantuan driver motor yang terpasang pada perangkat Arduino. Driver motor digunakan untuk memberi tegangan kerja pada kipas. Keluaran dari Arduino adalah nilai PWM dan nilai tersebut dikuatkan oleh driver motor untuk menggerakkan kipas. Pada hasil pengujian yang dilakukan, dapat dilihat hasil dari perubahan suhu berpengaruh pada nilai PWM kipas. Hasil pengujian dari nilai PWM pada kipas ditunjukkan dengan Tabel 4.

Tabel 4. Hasil pengujian nilai PWM kipas

\begin{tabular}{ccccc}
\hline $\begin{array}{c}\text { Suhu Terukur } \\
\left({ }^{\circ} \text { C) }\right.\end{array}$ & $\begin{array}{c}\text { Keadaan } \\
\text { Dingin }\end{array}$ & $\begin{array}{c}\text { Keadaan } \\
\text { Tepat }\end{array}$ & $\begin{array}{c}\text { Keadaan } \\
\text { Panas }\end{array}$ & Nilai PWM Kipas \\
\hline 23,7 & 1,00 & 0,00 & 0,00 & 27,58 \\
24,2 & 0,80 & 0,20 & 0,00 & 43,99 \\
24,7 & 0,30 & 0,70 & 0,00 & 56,31 \\
26,6 & 0,00 & 1,00 & 0,00 & 72,86 \\
27,3 & 0,00 & 1,00 & 0,00 & 72,86 \\
28,2 & 0,00 & 0,80 & 0,20 & 123,93 \\
28,7 & 0,00 & 0,30 & 0,70 & 163,22 \\
29,2 & 0,00 & 0,00 & 1,00 & 172,4 \\
35,5 & 0,00 & 0,00 & 1,00 & 172,4 \\
40,2 & 0,00 & 0,00 & 1,00 & 172,4 \\
\hline
\end{tabular}

Data pengujian pada Tabel 4 dapat diketahui nilai PWM maksimal dari kipas adalah 172,4 pada keadaan suhu diatas 29 derajat celcius dan nilai PWM minimal 27,58 saat suhu dibawah 24 derajat celcius.

\subsection{Pengujian Durasi Lampu}

Pengujian ini meliputi pengujian lampu dengan bantuan solid state relay yang terpasang pada perangkat Arduino. Berbeda dengan kipas dan pompa, tegangan kerja pada lampu yang digunakan adalah 220 volt AC maka perlu bantuan perangkat relay sebagai sakelar dari perangkat arduino ke lampu. Pada pengujian ini juga dapat dilihat hasil dari pengaruh suhu pada durasi on pada lampu. Hasil pengujian dari lampu dengan bantuan solid state relay ditunjukkan pada Tabel 5.

Tabel 5. Hasil pengujian durasi lampu

\begin{tabular}{ccccc}
\hline $\begin{array}{c}\text { Suhu Terukur } \\
\left({ }^{\circ} \text { C) }\right.\end{array}$ & $\begin{array}{c}\text { Keadaan } \\
\text { Dingin }\end{array}$ & $\begin{array}{c}\text { Keadaan } \\
\text { Tepat }\end{array}$ & $\begin{array}{c}\text { Keadaan } \\
\text { Panas }\end{array}$ & $\begin{array}{c}\text { Durasi On Lampu } \\
\text { (Detik) }\end{array}$ \\
\hline 23,7 & 1,00 & 0,00 & 0,00 & 1,37 \\
24,2 & 0,80 & 0,20 & 0,00 & 1,16 \\
24,7 & 0,30 & 0,70 & 0,00 & 0,92 \\
26,6 & 0,00 & 1,00 & 0,00 & 0,53 \\
27,3 & 0,00 & 1,00 & 0,00 & 0,53 \\
28,2 & 0,00 & 0,80 & 0,20 & 0,5 \\
28,7 & 0,00 & 0,30 & 0,70 & 0,37 \\
29,2 & 0,00 & 0,00 & 1,00 & 0,2 \\
35,5 & 0,00 & 0,00 & 1,00 & 0,2 \\
40,2 & 0,00 & 0,00 & 1,00 & 0,2 \\
\hline
\end{tabular}


Data pengujian pada Tabel 5 dapat diketahui durasi maksimal dari lampu adalah 1,37 detik pada keadaan suhu dibawah 24 derajat celcius dan durasi minimal 0,2 detik saat suhu diatas 29 derajat celcius.

\subsection{Pengujian Durasi Pompa}

Pengujian ini meliputi pengujian pompa dengan bantuan driver motor yang terpasang pada perangkat Arduino. Driver motor digunakan untuk memberi tegangan kerja pada pompa. Tegangan kerja dari pompa yang digunakan adalah 12 volt DC. Pada hasil pengujian yang dilakukan, dapat dilihat hasil dari perubahan kelembaban berpengaruh pada durasi on pompa. Hasil pengujian durasi pompa dapat dilihat pada Tabel 6 .

Tabel 6. Hasil pengujian durasi pompa

\begin{tabular}{ccccc}
\hline $\begin{array}{c}\text { Kelembaban } \\
\text { Terukur } \\
\text { (\% RH) }\end{array}$ & $\begin{array}{c}\text { Keadaan } \\
\text { Kering }\end{array}$ & $\begin{array}{c}\text { Keadaan } \\
\text { Tepat }\end{array}$ & $\begin{array}{c}\text { Keadaan } \\
\text { Basah }\end{array}$ & $\begin{array}{c}\text { Durasi On Pompa } \\
\text { (Detik) }\end{array}$ \\
\hline 57,8 & 1,00 & 0,00 & 0,00 & 1,37 \\
66,8 & 1,00 & 0,00 & 0,00 & 1,37 \\
68,4 & 0,80 & 0,20 & 0,00 & 1,24 \\
68,7 & 0,65 & 0,35 & 0,00 & 1,15 \\
69,5 & 0,25 & 0,75 & 0,20 & 0,88 \\
72,9 & 0,00 & 1,00 & 0,00 & 0,53 \\
77,3 & 0,00 & 1,00 & 0,00 & 0,53 \\
81,3 & 0,00 & 0,35 & 0,65 & 0,39 \\
81,5 & 0,00 & 0,25 & 0,75 & 0,36 \\
82,8 & 0,00 & 0,00 & 1,00 & 0,2 \\
92,1 & 0,00 & 0,00 & 1,00 & 0,2 \\
95,7 & 0,00 & 0,00 & 1,00 & 0,2 \\
\hline
\end{tabular}

Data pengujian pada Tabel 6 menunjukkan bahwa durasi maksimal dari pompa adalah 1,37 detik pada keadaan kelembaban dibawah $68 \%$ RH dan durasi minimal 0,2 detik saat kelembaban diatas $82 \% \mathrm{RH}$.

\subsection{Pengujian Jangkauan Komunikasi ESP8266}

Pengujian jangkauan komunikasi dari ESP8266 ini dilakukan pada dua area, pertama pengujian dilakukan di dalam ruangan, kedua pengujian dilakukan diluar ruangan. Pengujian dilakukan untuk melihat jangkauan komunikasi yang memungkinkan digunakan. Pengujian tersebut untuk menentukan kekuatan jangkauan antara alat yang dibuat dengan PC sebagai penerima data. Hasil pengujian jarak jangkau data dari ESP8266 ditunjukkan dengan Tabel 4.

Tabel 7. Hasil pengujian komunikasi ESP8266

\begin{tabular}{ccccc}
\hline $\begin{array}{c}\text { Jarak } \\
\text { (Meter) }\end{array}$ & $\begin{array}{c}\text { Di Dalam Ruangan } \\
\text { Terhubung }\end{array}$ & $\begin{array}{c}\text { Di Luar Ruangan } \\
\text { Terhubung }\end{array}$ & $\begin{array}{c}\text { Terhubung } \\
\text { Tidak } \\
\text { Terhubung }\end{array}$ \\
\hline 5 & $\sqrt{ }$ & - & $\sqrt{ }$ & - \\
10 & $\sqrt{ }$ & - & $\sqrt{ }$ & - \\
15 & - & $\sqrt{ }$ & $\sqrt{ }$ & - \\
20 & - & $\sqrt{ }$ & $\sqrt{ }$ & - \\
25 & - & $\sqrt{ }$ & $\sqrt{ }$ & - \\
30 & - & $\sqrt{ }$ & - & $\sqrt{ }$ \\
35 & - & $\sqrt{ }$ & - & $\sqrt{ }$ \\
40 & - & $\sqrt{ }$ & - & $\sqrt{ }$ \\
45 & - & $\sqrt{ }$ & - & $\sqrt{ }$ \\
50 & - & $\sqrt{ }$
\end{tabular}

Berdasarkan Tabel 7, didapatkan hasil pengujian pertama di dalam ruangan yang mampu melakukan komunikasi dengan jangkauan \pm 10 meter. Kemudian pada pengujian kedua, yaitu diluar ruangan mampu melakukan komunikasi dengan jangkauan \pm 25 meter. Akan tetapi, pada jangkauan terjauh tersebut aliran komunikasi terkadang putus dengan sendirinya. Dari hasil pengujian ini, didapatkan kemampuan jangkauan wifi ESP8266 bisa berkurang ketika berada di dalam ruangan, hal ini disebabkan adanya penghalang saat berada di dalam ruangan. 


\subsection{Pengujian Monitoring Keseluruhan}

Pada pengujian ini, dilakukan pengujian monitoring data yang sudah dikirimkan oleh ESP8266, kemudian data diterima oleh PC. Data tersebut akan ditampilkan dengan menggunakan web ESP-LINK atau telnet.

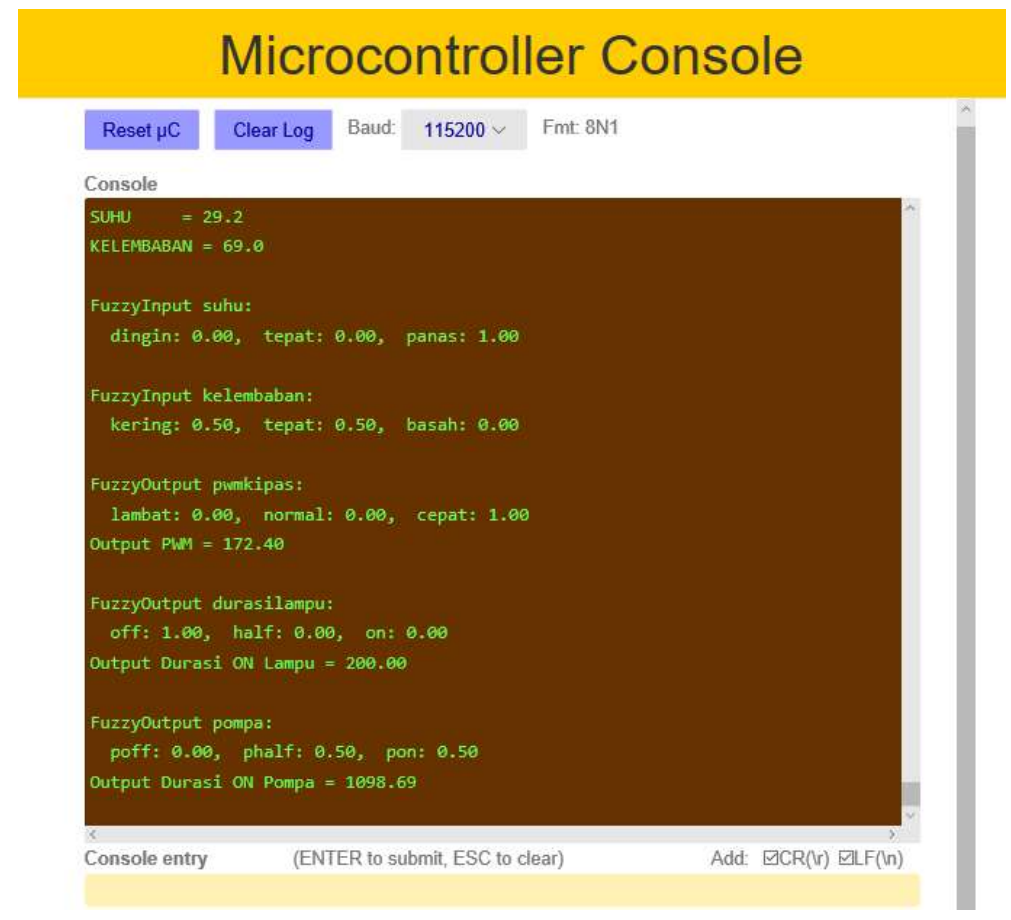

\section{Gambar 9. Hasil Pengujian Monitoring dengan ESP-Link}

Pada Gambar 9, data ditampilkan oleh sistem pengendali yang telah dibuat. Data tersebut terdiri dari waktu pengambilan data setiap 2 detik yaitu nilai suhu dan kelembaban yang didapat dari pembacaan sensor AM2301, nilai PWM dari kipas, durasi dari lampu dan durasi dari pompa.

\section{KESIMPULAN}

Berdasarkan hasil dari semua tahapan yang sudah dilakukan mulai dari tahap perancangan, tahap implementasi, tahap pengujian dapat diterik kesimpulan bahwa strategi optimisasi sistem pengendali yang dikembangkan adalah dengan pendekatan logika fuzzy yang mengakomodasi parameter input berupai suhu dan kelembaban sedangkan paremater output yang dikaitkan dengan actuator berupa kipas, lampu dan pompa. Dari hasil pembacaan dapat dilihat output yang dihasilkan sudah sesuai dengan perancangan fungsi keanggotaan dari masing-masing output. Besaran nilai PWM untuk pengaturan kipas didapatkan nilai maksimal adalah 172,4 pada keadaan suhu diatas 29 derajat celcius dan nilai minimal 27,58 saat suhu dibawah 24 derajat celcius. Pengendalian lampu didapatkan durasi maksimal adalah 1,37 detik pada keadaan suhu dibawah 24 derajat celcius dan durasi minimal 0,2 detik saat suhu diatas 29 derajat celcius. Pengendalian pompa didapatkan durasi maksimal adalah 1,37 detik pada keadaan kelembaban dibawah 68\% RH dan durasi minimal 0,2 detik saat kelembaban diatas 82\% RH. Kemampuan jangkauan komunikasi pada modul wifi ESP8266 dapat berkurang ketika berada pada area di dalam ruangan. Jangkauan komunikasi maksimum sebesar \pm 10 meter saat berada didalam ruangan dan \pm 25 meter saat berada di luar ruangan. Pengambilan data dari sistem pengendali yang telah dibuat sudah ditampilkan menggunakan telnet ataupun esplink.

\section{DAFTAR PUSTAKA}

[1] A. Hafiz, Fardian, And A. Rahman, "Rancang Bangun Prototipe Pengukuran Dan Pemantauan Suhu, Kelembaban Serta Cahaya Secara Otomatis Berbasis Iot Pada Rumah Jamur Merang," Kitektro : Jurnal Online Teknik Elektro, Vol. 2, P. 7, 2017.

[2] Ramdani And T. B. Santoso, "Penerapan Fuzzy Inference Sistem Untuk Kontrol Suhu Dan Kelembaban Budidaya Jamur Tiram Berbasis Mikrokontroler" Jurnal Ilmiah Fakultas Teknik Limit's Vol. 12 No. 1 Maret 2016 
[3] Sutarman, "Keragaan dan Produksi Jamur Tiram Putih (Pleurotus Ostreatus) Pada Media Serbuk Gergaji dan Ampas Tebu Bersuplemen Dedak dan Tepung Jagung," Jurnal Penelitian Pertanian Terapan, vol. 12, p. 6, 2012.

[4] A.A. Sulistiono, S. Sumardi, MA. Riyadi. Perancangan Sistem Pengendali Pada Prototype Rumah Jamur Menggunakan PLC OMRON CPM1A. TRANSIENT. 2015 Nov 18;4(3):426-32.

[5] Yamin M. Budidaya Jamur Kuping dan Tiram dengan Teknologi Pengendalian Suhu. Jurnal Pangan. 2016 Jun $15 ; 19(2): 189-95$.

[6] S. Waluyo, R. Wahyono, B. Lanya, M. Telaumbanua. Pengendalian Temperatur dan Kelembaban dalam Kumbung Jamur Tiram (Pleurotus sp) Secara Otomatis Berbasis Mikrokontroler. AGRITECH. 2018;38(3):282-8.

[7] K. M. Passino and S. Yurkovich, Fuzzy control. Menlo Park, Calif: Addison-Wesley, 1998.

[8] F. Solikin, "Aplikasi Logika Fuzzy Dalam Optimisasi Produksi Barang Menggunakan Metode Mamdani dan Metode Sugeno," p. 100, 2011.

[9] D. Ismawati, "Perbandingan Jumlah Membership dan Model Fuzzy Terhadap Perubahan Suhu Pada Inkubator Penetas Telur,” p. 122, 2017.

[10] U. J. Shobrina, R. Primananda, and R. Maulana, “Analisis Kinerja Pengiriman Data Modul Transceiver NRF24101, Xbee dan Wifi ESP8266 Pada Wireless Sensor Network," p. 8.

[11] I. S. Wicaksana, F. I. Ubaidillah, Y. P. Hadi, S. T. Wahyu, I. Istiadi, "Perancangan Sistem Monitoring Suhu Gudang Berbasis Internet Of Things (Iot),” P. 9, 2018.

[12] R. S. Putri, M. I. Fanani, I. I. Kurniawan, E. P. O. Danawan, K. I. F. Sugiarto, I. Istiadi, "Penerapan Teknologi Pengendali Fermentasi Tempe Bagi Usaha Krudel Lariso Kelurahan Purwantoro Kota Malang," Proceeding CIASTECH, 2018. 